\title{
ما اختاره الإمام أبو الطيب بن غلبون من الروايات والوجوه في كتابه الإرشاد: عمعًا وتحقيقًا
}

\section{Ömer TÜRKMEN ${ }^{*}$}

Atıf/Cite as: Türkmen, Ömer. "Me'htârehu'l-imâm Ebu't-Tayyîb ibn Galbûn mine'r-rivâyât ve'lvucûh fî kitâbihi'l-İrşâd: Cem'an ve tahkîkan". Recep Tayyip Erdoğan Üniversitesi İlahiyat Fakültesi Dergisi 20 (2021), 258-280.

\section{Ebu't-Tayyib İbn Galbûn'un Kıraat Tercihlerini Derleme ve Değerlendirme (el-İrşâd Adlı Eseri Bağlamında)}

Öz: Bu çalışma, Halepli kıraat âlimi Ebu't-Tayyib b. Galbûn'un (ö. 389/999) elIrşâd fi kurââti'l-eimmeti's-seb'a ve şerhi usûlihim adlı eseri çerçevesinde Kur'an-1 Kerim kıraatleri noktasında nasıl bir tercih (ihtiyâr) ve araştırmada bulunduğunu; ayrıca kıraatleri usûl ve ferş farklılıklarına göre nasıl tertip ettiğini incelemektedir. O'nun söz konusu tercihleri, kıraat ilmi açısından büyük bir önemi sahiptir. Zira bu tercihler, kıraat âlimi Ebu't-Tayyib b. Galbûn'un dilbilim ve kıraat teorisi konusunda sahip olduğu ilmî derinliğe, bu ilim dalındaki yetkinliğine ve öncülügüune işaret etmektedir. Bunun yanı sıra İbn Galbûn'un tercih ettiği ve benimsediği vecihlerde çoğunlukla kendisinden önceki kıraat ve dil âlimlerinin yöntemlerine bağlı kaldığı ifade edilmelidir.

Anahtar Kelimeler: Kıraat, İbn Galbûn, el-İrşâd, Tercih (İhtiyar), Kıraat usûlleri.

* Dr., Uludağ Üniversitesi, Bursa, Türkiye, omerturkmen@uludag.edu.tr, ORCID: www.orcid.org/0000-0001-8509-172X 


\section{Compiling and Evaluating Ebu't-Tayyib Ibn Galbūn's Preferences in His Book al-Irshād}

Abstract: This research examines what preferences (ikhtiyār) Ebu't-Tayyib b. Galbūn, who is the recitation scholar from Aleppo, made within the frame of his book al-Irshād fī qurāāti'l-eimmeti's-seb'a ve sharhi usūlihim, concerning the recitations of Qur'an-1 Karim and what he researched about, furthermore how he arranged the qiraats according to the usūl and farsh differences. His mentioned preferences are meant a lot in terms of the qiraat discipline. Yet this preferences indicate the recitation scholar Ebu' t-Tayyib b. Galbūn' s scholarly depth in linguistics and qiraat theory, his competence and leadership in this discipline. Besides, it must be verbalized that about wajhs which Ibn Galbūn preferred and adopted are mostly abode the methods of the qiraat and linguistics scholars before him.

Keywords: Qiraat, Ibn Galbūn, al-Irshād, Preferences (Ikhtiyār), Qiraat methods.

$$
\begin{aligned}
& \text { الخلاصة: تناول البحث جمع ما اختاره الإمام أبو الطيب بن غلبون الإنة المقرئ الحلبي (ت 389هـ) في القراءات }
\end{aligned}
$$

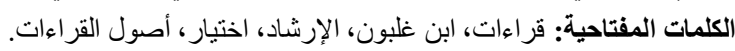

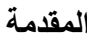

بسم الله الرحمن الرحيم

$$
\text { الحمد الله ربّّ العالمين، و الصلاة و السلام على سيدنا محمد، و على آله وصحبه أجمعين، وبعد: }
$$

فإنَّ ظاهرة الاختيار في القراءات تُشكل ظاهرةً مهمَّةً من ظو اهر علم القر اءات القر آنية، فهي تدلُّ على وجود

$$
\text { سببٍ جعل العالم أو المقرئ يختار هذا الوجه على غيره. }
$$

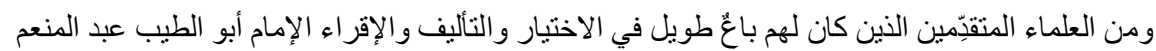

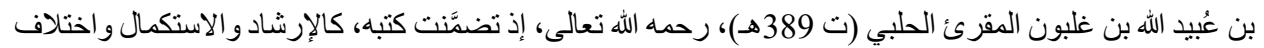

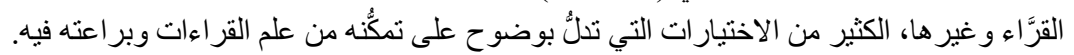

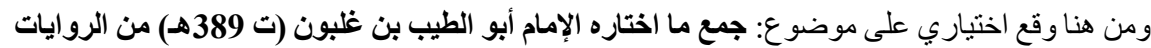

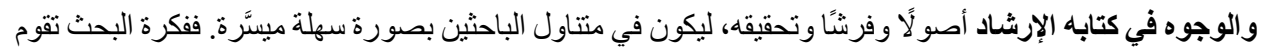

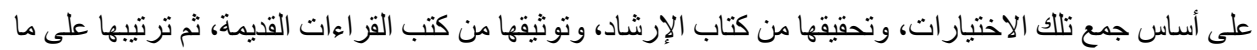
يو افق ترتيب كتب القراءات.

وقد علمتُ أن الطالب شعلان جاسم المفرجي قد جمع اختيار ات ابن غلبون ودرسها در اسةً لغويةً في رسالته

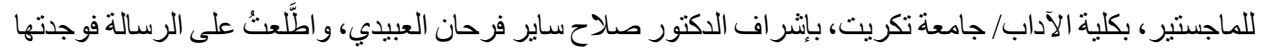

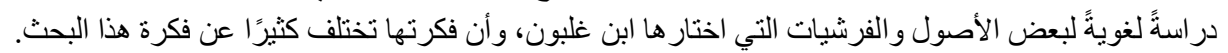
وقد اقتضت طبيعة العمل أنَّ أنتَّعَ في بحثي هذا، الخطة الآتية: 
المبحث الأول: مفهوم الاختيار ، وترجمة أبي الطيب بن غلبون، وفيه مطلبان:

المطلب الأول: مفهوم الاختبار.

المطلب الثاني: ترجمة أبي الطيب بن غلبون.

المبحث الثاني: ما اختاره أبو الطيب بن غلبون في كتابه الإرشاد، وفيه ثلاثة مطالب:

المطلب الأول: ما اختاره في الأداء و الضبط والطرق و الروايات.

المطلب الثاني: ما اختاره في الأصول.

المطلب الثالث: ما اختاره في الفرش.

ثُمَ الخاتمة التي تضمنت نتائج البحث.

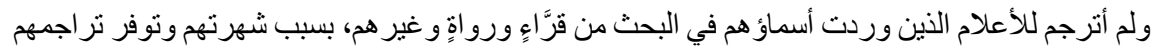

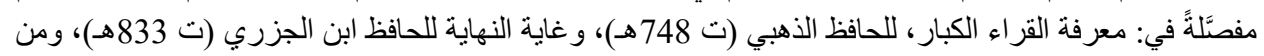

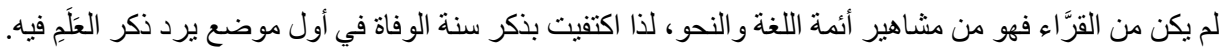
أمَّا المصطلحات التي وردت فقد أحلت إلى مصادر تعريفها في الهامش، وحاولت أن لا أُثقل الهامش، ولا لاهن أُطيل فيه، طلبًا للاختصار و الإيجاز .

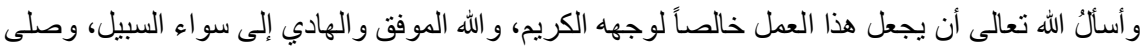

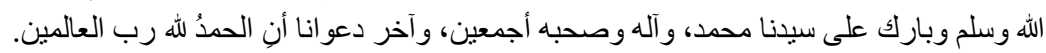
المبحث الأول

\section{مفهوم الاختيار، وترجمة أبي الطيب بن غلبون}

المطلب الأول

مفهوم الاختيار 1

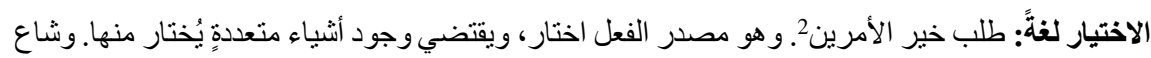

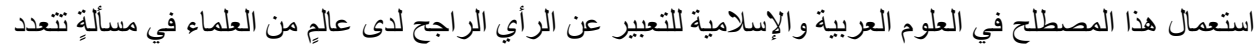

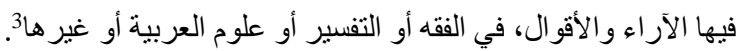

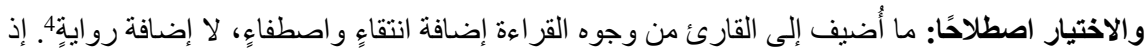

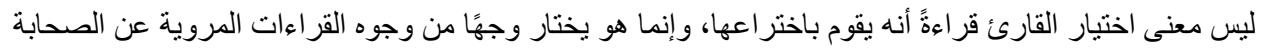

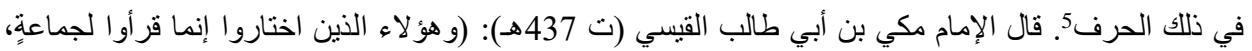

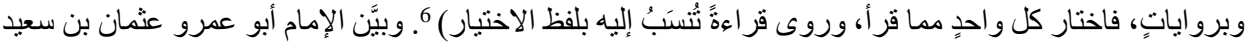

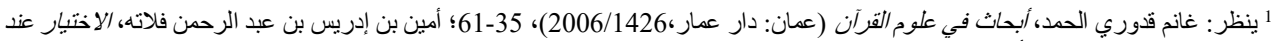

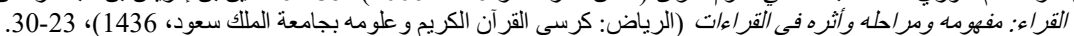

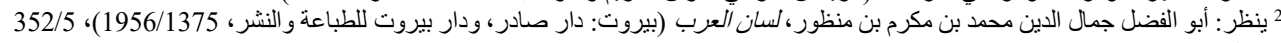

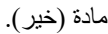

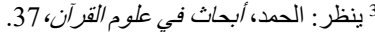

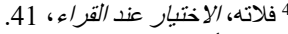

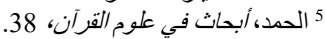
6 مكي بن أبي طالب القيسي، الإبانة عن معاني القراءات ، تحقيق: محيي الدين رمضان (المملكة العربية السعودية: دار المأمون للتراث، 1979/1399)، 49. 


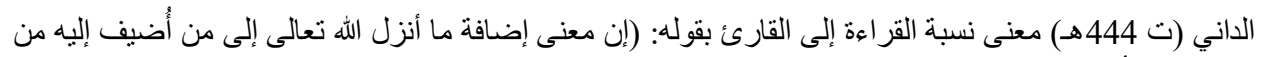

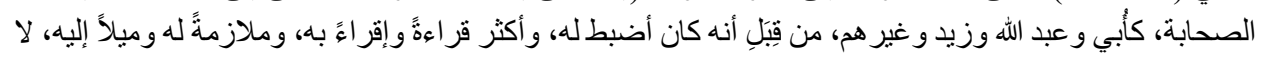

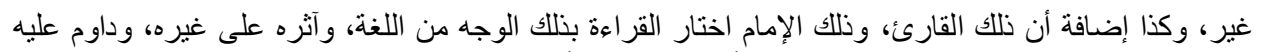

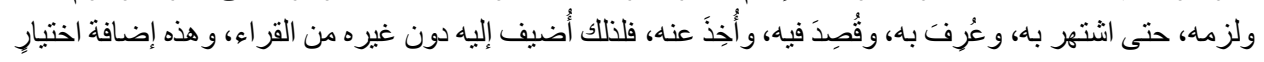

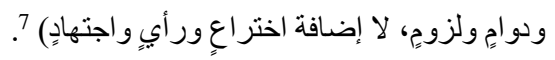

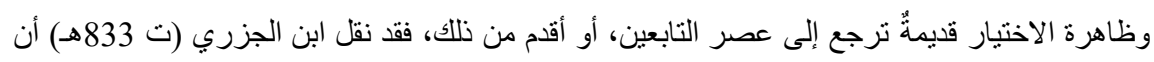

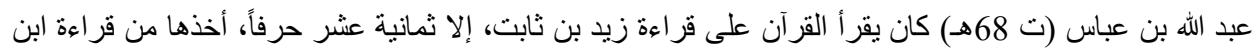

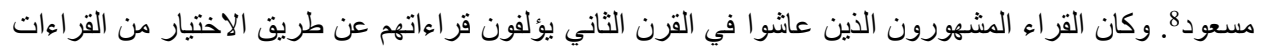

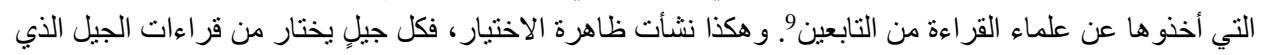

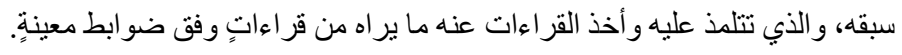

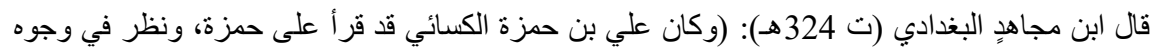

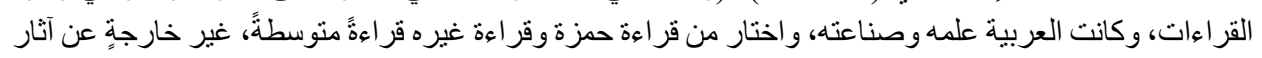

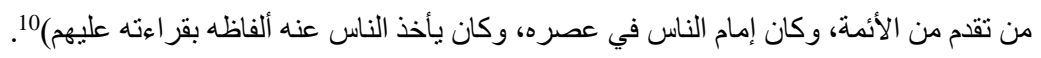

وكان القراء يخضعون في اختبار هم القر اءة إلى ضو ابط أو شروط، وكانت هذه الثروط معتمدةً لدى علماء

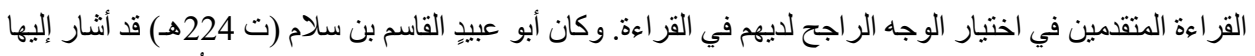

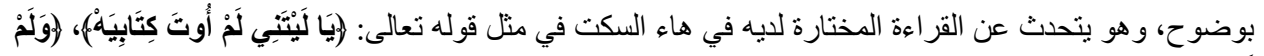

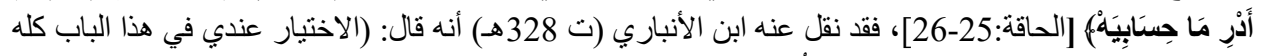

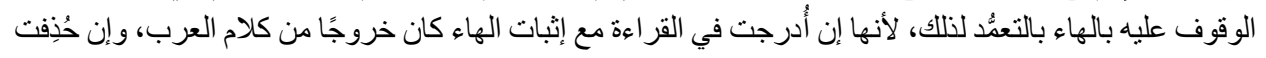

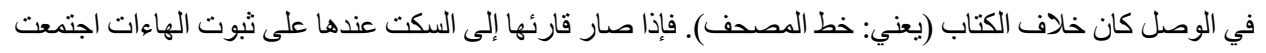

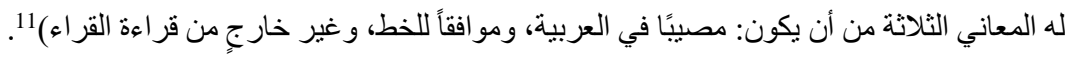
وتعددت الاختبارات في القراءات القرآنية، فالقرَّاء لهم اختيارات، ومؤلفو كتب القراءات لهم اختيارات

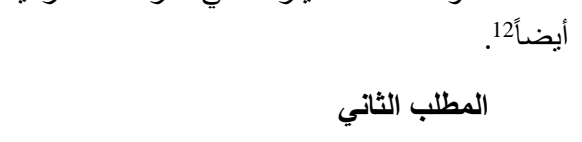

\section{الإمام أبو الطيب بن غلبون وسيرته العلمية}

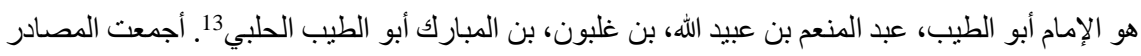

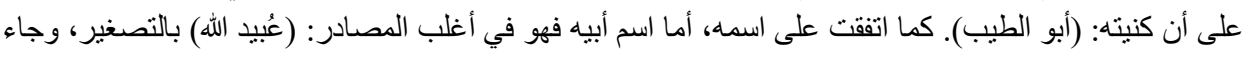

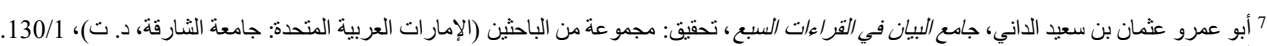
8 أبو الخير ابن الجزري، غاية النهاية في طبقات القراء، عني بنشره: ج. بر اجستر اسر (بيروت: دار الكتب العلمية، 2006/1427)،

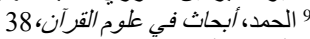

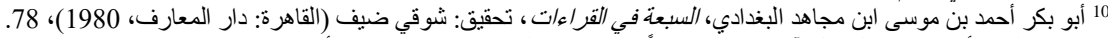

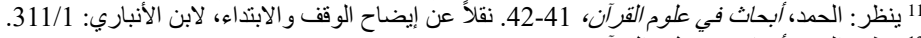

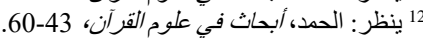

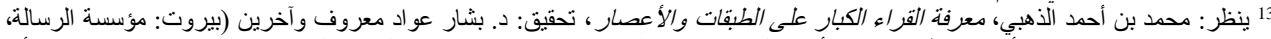

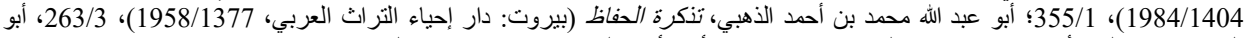

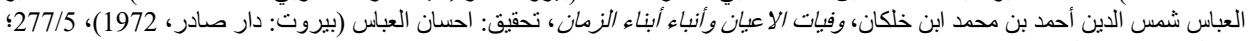


في بعضها14: عبد الله، و الصواب الأول، وهو (عبيد الله)15، و هو ما نصنَّ عليه الأئمة الضابطون كالحافظين: الذهبي

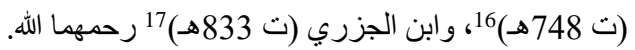

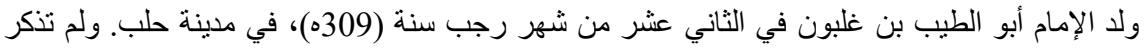

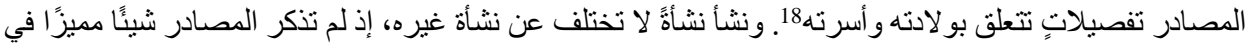

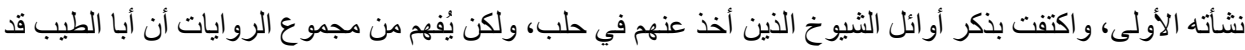

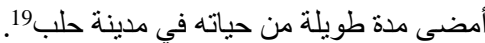

\section{وتتلمذ أبو الطيب بن غلبون على عددٍ كبيرٍ من الثيوخ والعلماء، منهه:} 1- إبر اهيم بن عبد الرزاق بن الحسن العِجْلي الأنطاكي (ت 339ه) 20، ذكره أبو الطيب في كتابه الإرشاد في مواضع متعدةٍة، وذكر أنه قر أ عليه بأنطاكية.

2- أبو العباس أحمد بن محمد الجَبلي، ذكر ابن الجزري أن أبا الطيب قرأ عليه21. وذكره أبو الطيب في الإرشاد. 3- إبر اهيم بن محمد بن مروان، الثامي الأصل، المصري الدار 22، وهو المصري الوحيد الذي قر أ عليه أبو الطيب، وذنكره في كتابه الإرشاد.

4ـ أحمد بن محمد بن بلال، البغدادي 23 ذكره أبو الطيب في مو اضع متعددةٍ في أسانيد قر اءة ابن عامر. 5- الحسن بن حبيب بن عبد الملك الحَصنائري، الدمشقي، الثنافعي (ت 338ه) 24، وقد أخذ عنه ابن غلبون الفقه و القر اءات، وذكره في مواضع متعددةٍ في كتابه الإرشاد. 6ـ الحسين بن أحمد بن خَالَيْه، النحوي الحلبي (ت370ه)، وقد ذكره أبو الطيب في مو اضع كثثرة في كتابه الإرشاد.

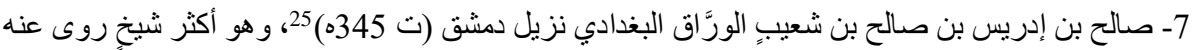
أبو الطيب في كتابه الإرشاد، و غير هم.

ونزل أبو الطيب بن غلبون مصر و استقر بها، فقصده طلبة العلم للقر اعة عليه والانتفاع به، فمن أبرز تلاميذه26: 1- 2 - أحمد بن أبي الربيع الأندلسي (ت446هـ).27.

14 ينظر : عبد الحي بن العماد الحنبلي، شذرات الذهب في /خبار من ذهب (القاهرة: مكتبة المقدسي، 1350)، 131/3؛ أبو الطيب عبد المنعم بن عبيد

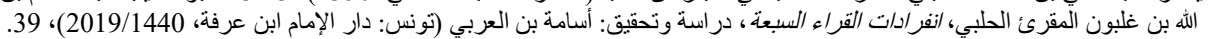

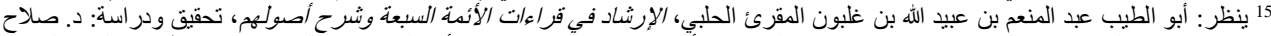

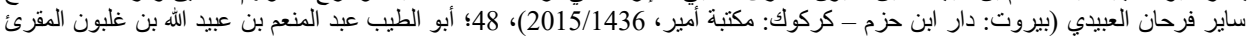

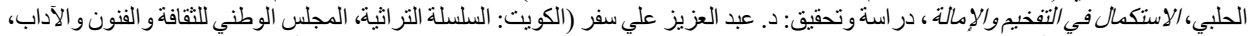

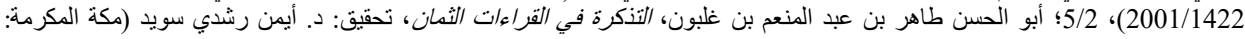
30/1، 1991/1412

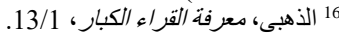

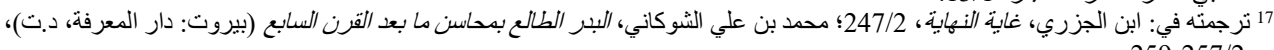
259-257/2

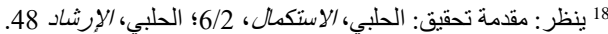

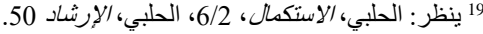

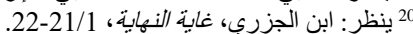

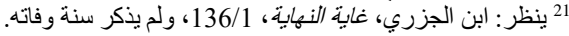

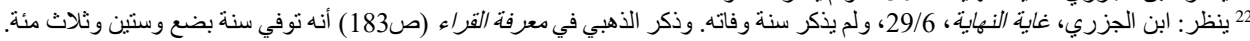

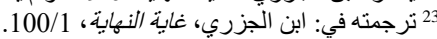

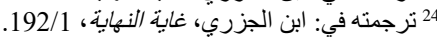

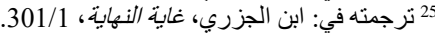

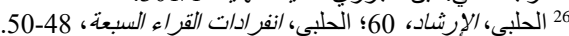
27 ابن الجزري، غاية النهاية، 26 الجناني، 


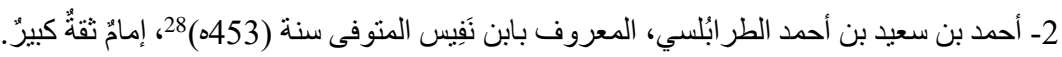

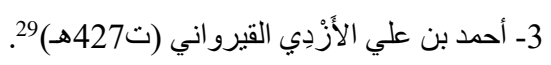

4- أحمد بن علي بن هانشم، تاج الأئمة (ت 445هـ) 30، شيخ حافظ.

5- أبو عمر الطََُّنْكِي، أحمد بن محمد بن عبد الله المعروف بالمَعَافِرِي الأنلسي (ت 429هـ)

$$
\text { 1- محمد بن سفيان القيرواني المالكي (ت 415هـ)32، صاحب كتاب الهادي. }
$$$$
\text { 2- مكي بن أبي طالب القيسي، القيرواني الأندلسي (ت437هـ)33، و غير هم. }
$$

توفي الإمام أبو الطيب__رحمه الله_بمصر يوم الجمعة لسبع خلون لثهر جمادى الأولى سنة (389ه) بعد عمر

يناهز الثمانين عاماً 34.

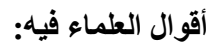

تلقى الإمام أبو الطيب علومه على أكابر علماء عصره في القراءات القرآنبة والحديث النبوي الثريف و الفقه

$$
\text { الثافعي، وكان مقصد العلماء من أقطار العالم الإسلامي. }
$$

وقد أثنى عليه علماء عصره ومن ترجم له من كتاب السير والتراجم، و أقو الهم فيه شهادات لهذا الرجل العالم العلَّمة، فمن هذه الأقو ال و الثهادات:

1- قال الإمام الداني (ت 444هـ)، ونقله عنه الحافظان: الذهبي وابن الجزري: (كان حافظًا للقر اءة ضابطًا، ذا

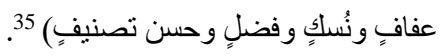

2- وقال الحافظ الذهبي (ت 748هـ): (قرأ عليه جماعةٌ كثثرةٌ، ورُوي عنه الحديث، وكان ثقةً محققًا بعيد

الصيت)

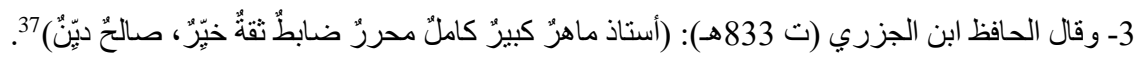

4- وقال فيه ابن العماد الحنبلي (ت 1089 هـ)38: (أبو الطيب بن غلبون عبد المنعم بن عُبيد الله الحلبي المقرئ،

الثافعي، صاحب الكتب في القراءات) 39.

28 ترجمته في: ابن الجزري، غاية النهاية، 56/1، ترجية

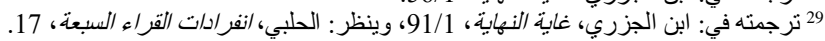

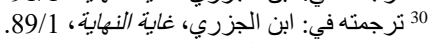

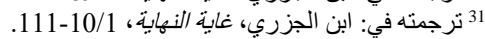

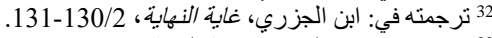

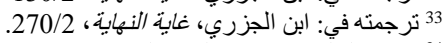

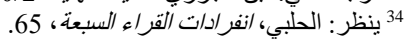

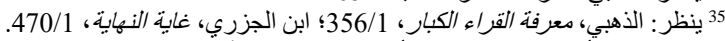

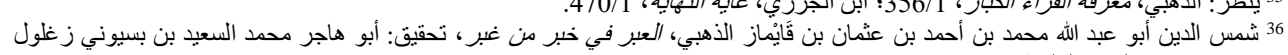

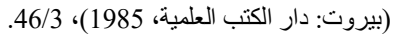

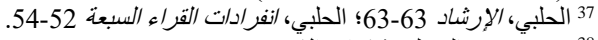

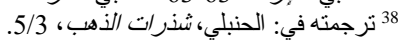

39 الحنبلي، شذرات الذهب: 313/3. 


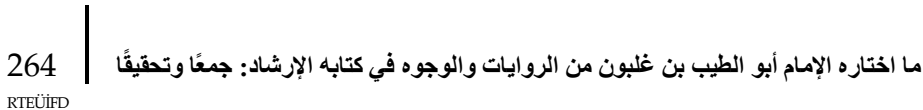

آثاره العلمية (مؤلفاته):

ألَّف الإمام أبو الطيب بن غلبون، رحمه الله تعالى، الكثير من الكتب في القراءات القرآنية وموضوعاتها المتنو عة"40، وفي ما يأتي بيانٌ لما وققتُ عليه:

1- اختصار القول في (كلا، بلى، نعم)، لم تذكره كتب التراجم و الفنون، وهي رسالةُ لطيفةٌ صغيرة الحجم تقع في

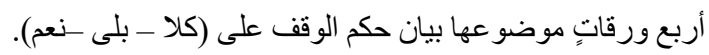
2- اختلاف القراء في (أنَّ وإنَّ) المفتوحة و المكسورة و المشددة و المخففة 41. 3- الإرشاد في قر اءات الأئمة السبعة وشرح أصولهمب، وهذا الكتاب مشهورٌ جدًا، إذ لا يُذكر أبو الطيب في موضعٍ حتى يقال: (و هو مؤلف كتاب الإرشاد في القراء اءتات السبع).

4- حديقة البلاغة ودوحة البراعة، وهذا الكتاب صنفه أبو الطيب بن غلبون ردًا على ما صنفه أبو عامر بن خَرْشَنَة

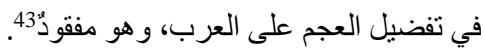

5- رسالة الاستعاذة، ذكر ها المستشرق كارل بروكلمان، و أشار إلى وجود نسخةٍ منها في مكتبه جوتا ـ ألمانيا (8) برقم (1).

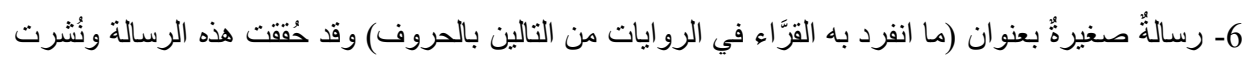

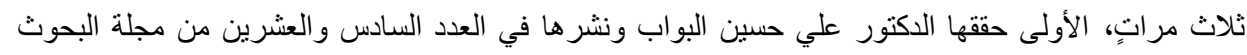

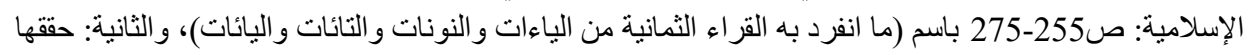

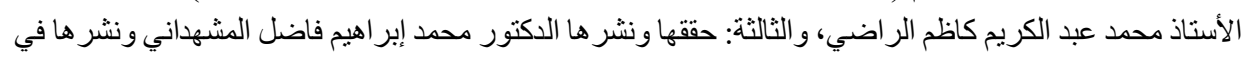

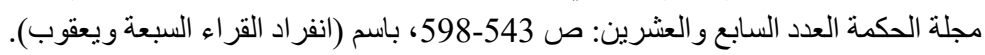
7ـ كتاب (كلا، بلى)، وهو أوسع من السابق، أثشار إليه ابن غلبون في مطلع الكتاب الذي قبله، وهو مفقود.. 8- كتاب إكمال الفائدة في القراءات السبع، وذكره ابن خير في فهرسته. 9- كتاب الاستكمال لبيان جميع ما يأتي في كتاب الله عز وجل في مذاهب القر اء السبعة في التفخيم و الإمالة وما كان

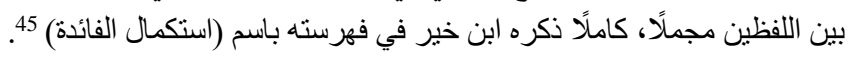
10- كتاب التهذيب لاختلاف قر اءة نافعٍ في رواية ورشٍ وقالون عن نافعٍ، وهو مفقود. 11- كتاب العدل في القر اءة، وهو مفقودٌ أيضًا. 12- كتاب المرشد في القراءات السبع، و هو مفقود وقد ذكره ابن خير في فهرسته.

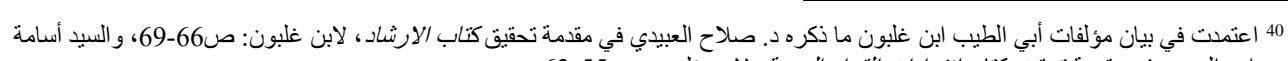

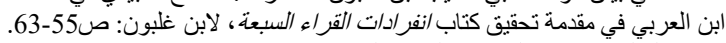

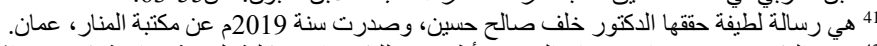

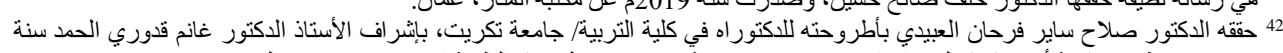

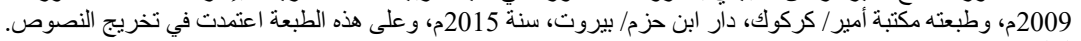

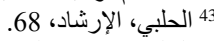

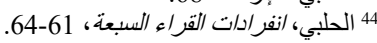

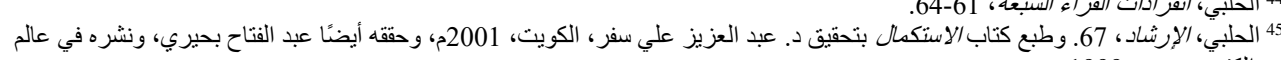
الكتب، بيروت 1999م، 
13- كتاب انفر ادات القرَّاء ذكره ابن غلبون في كتاب الاستكمال، عندما قال: (وقد ذكرت أصل كل و احدٍ منهما يعني

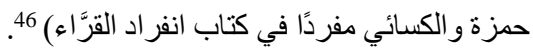

14- كتاب هاءات الكناية في القرآن الكريم. وهذا الكتاب لم يذكره أحدٌ من أصحاب التراجم، ولكن ذكره أبو الطيب

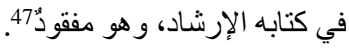

هذه جملة ما أمكن جمعه من أسماء مؤلفات الإمام ابن غلبون، رحمه الله تعالى رحمةً واسعةً، وأحسن إليه.

$$
\text { المبحث الثاني }
$$

\section{ما اختاره الإمام أبو الطيب بن غلبون في كتاب الإرشاد \\ المطلب الأول}

\section{القراءات و الروايات والطرق 48}

اختار ابن غلبون بعض الروايات و الطرق للقرَّاء السبعة المشهورين، وفضلَّها على غير ها، وذلك بسبب ضو ابط وضَعَها لنفسه، أهمها اثنان هما:

\section{(1) إيثار الرواية والدقة في النقل وترك القياس في ما ليس له أصلّ:}

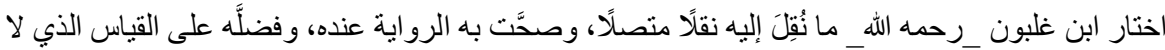

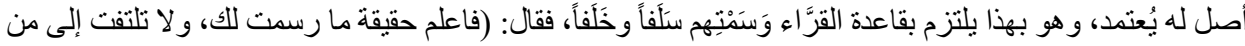

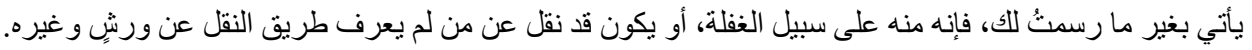

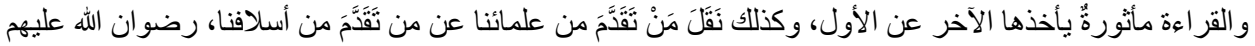

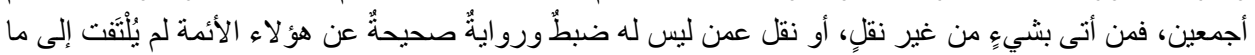

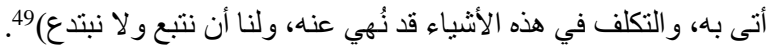

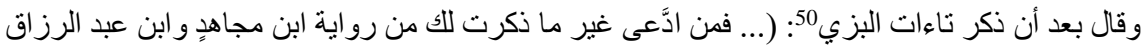

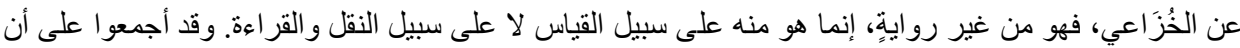

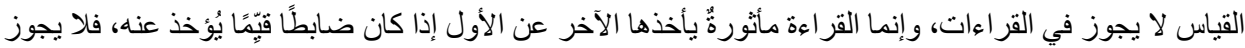

فيها القياس)

\section{(2) اتباع طريق القرَّاء وأهل اللغة وعدم الخروج عنه:}

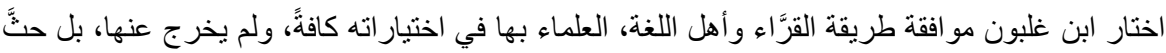

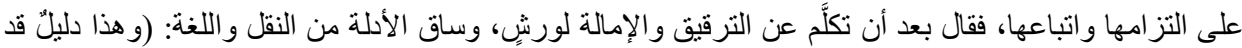

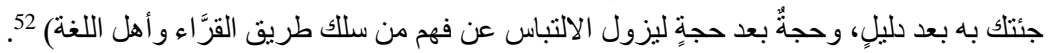

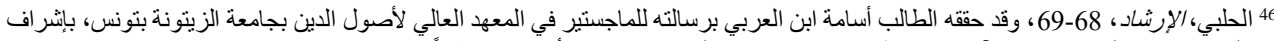

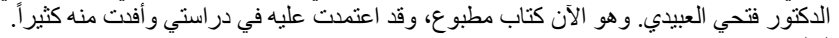

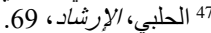

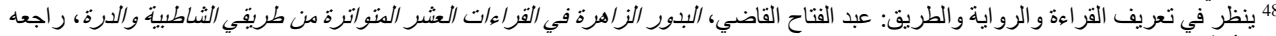

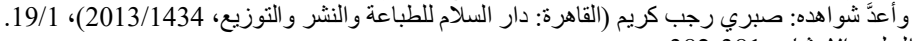

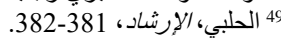

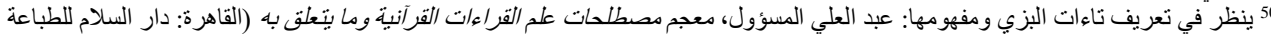

$$
\begin{aligned}
& \text { و النشر و التوزيع، 2007/1428)، } 112 . \\
& 51 \text { الحلبي، الإرشاد، } 450 \text { النبع، } \\
& 52 \text { الحلبي، الإرشاد، } 383 .
\end{aligned}
$$


266

ما اختاره الإمام أبو الطيب بن غلبون من الروايات والوجوه في كتابه الإرشاد: جمعًا وتحقيقًا

RTEÜiFD

$$
\text { أما الروايات والطرق التي اختارها ابن غلبون: }
$$

(1) طريق روايتي ابن ذَكْوان وهثام، عن ابن عامر الثشامي:

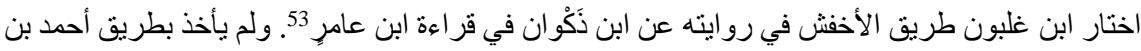

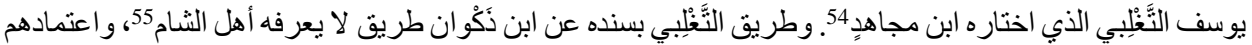

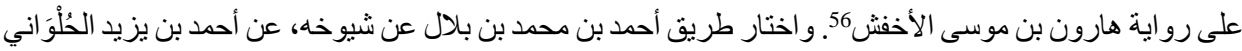

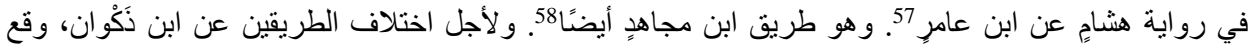

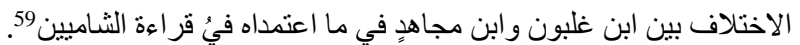

\section{(2) طريق يحيى ابن آدم عن أبي بكر (شُعبة) عن عاصم:}

اختار ابن غلبون طريق يحيى بن آدم عن شعبة عن عاصم06، مو افقًا في ذلك جمهور العلماء، وقد ذكر طريق

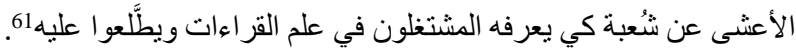

$$
\text { المطلب الثاني }
$$

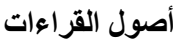

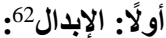

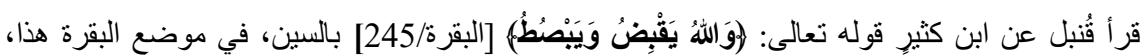

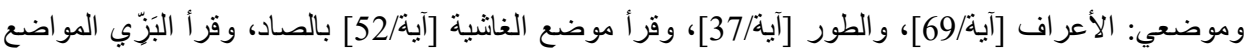

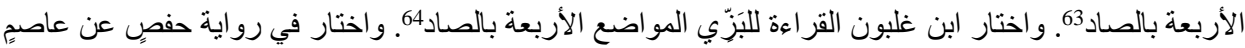
قر اءة موضعي البقرة والأعر اف بالوجهين، وبالصناد الصناد فقط في الطور و الغانشية.65.

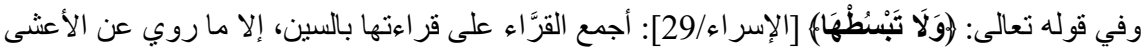

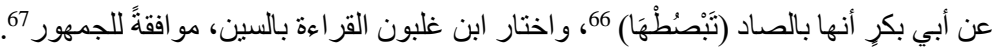

53 ينظر : الحلبي، الإرشاد، 192، 217 : 217. 54

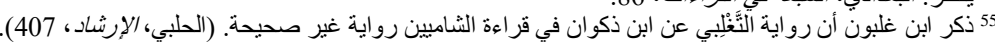

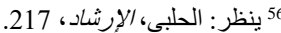

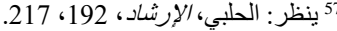

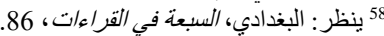

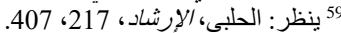

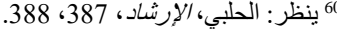
161 ينظر : الحلبي، الإرشاد، 606

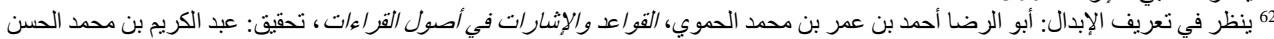

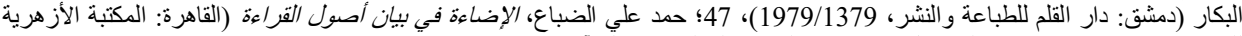

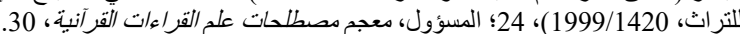

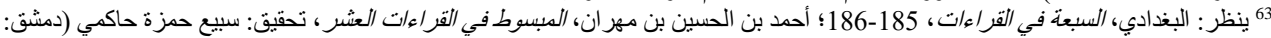

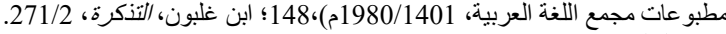

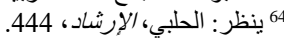

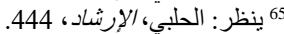
66 ينظر : البغدادي، السبعة في القراءات ، 1402، 186؛ مكي بن أبي طالب القيسي، التبصرة في القراءات السبع، تحقيق: د. محمد غوث الندوي (الهند: الدار

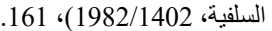
67 ينظر : الحلبي، الإرشاد، 587. 


\section{ثانيًا: الاختلاس 68}

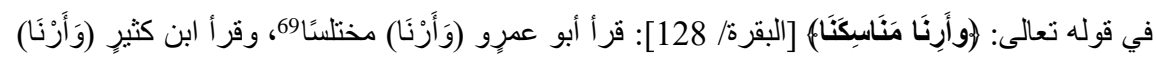

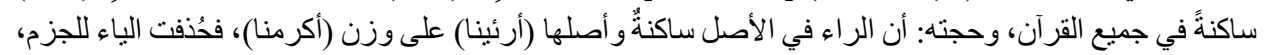

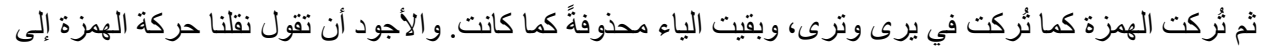

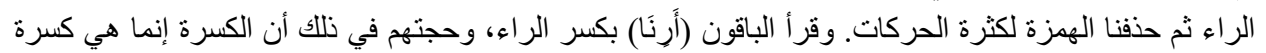

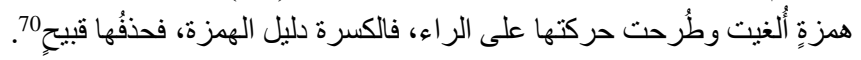

واختار ابن غلبون في هذا الموضع وما شابهه الاختلاس لأبي عمرِو البصري، فقال: (وبقي أصلٌ آخرّ فيما

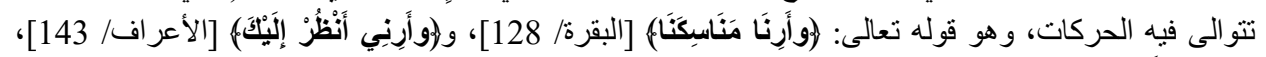

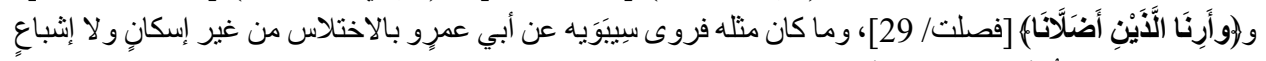

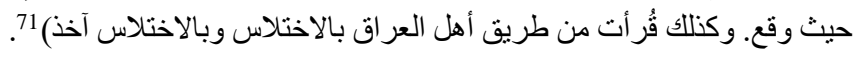
فابن غلبون هنا يُعِلِّلُ اختياره بمتابعة القرَّاء، و عدم الخروج عن سننهم وما أجمعوا عليه من جهتي الرواية و الدراية.

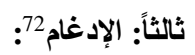

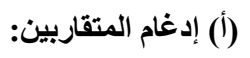

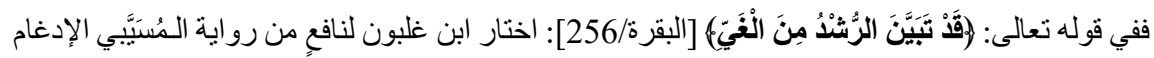

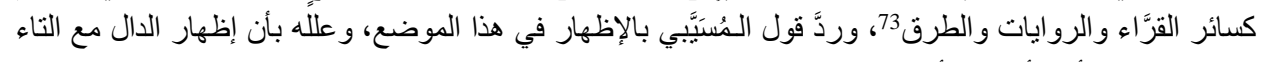
رديءٌ جدًا، من أجل أن التاء أخت الدال

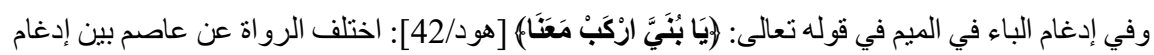
الباء في الميم و عدمه، واختار ابن غلبون الإدغامجامئ.

\section{(ب) الإدغام الكبير لأبي عمرِو:}

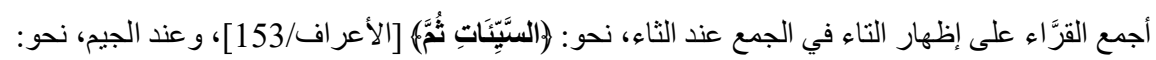

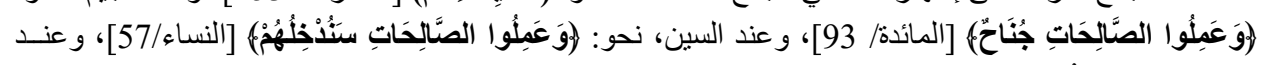

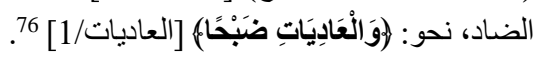

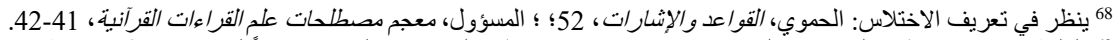

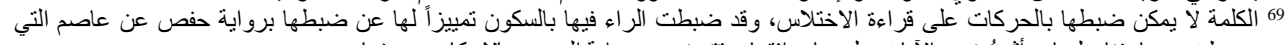

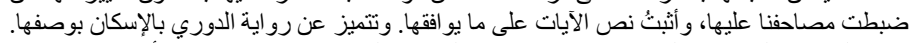

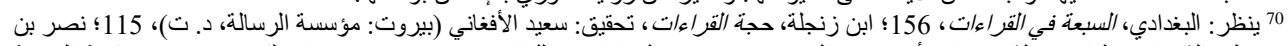

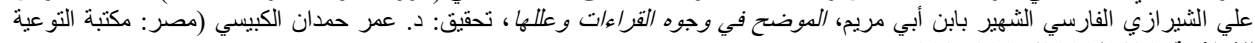

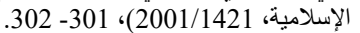

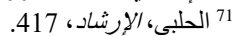

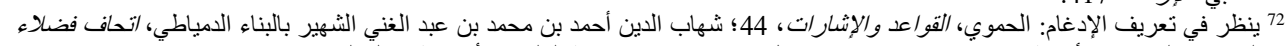

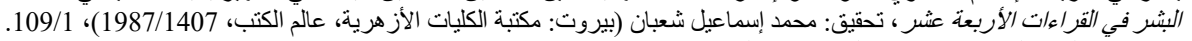

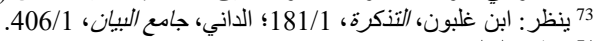

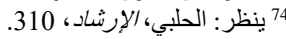

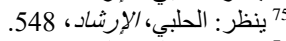
76 ينظر ابن غلبون، التنكرة، 182/1؛ الداني، جامع البيان، 408/1. 


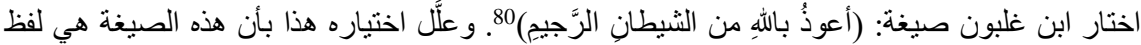

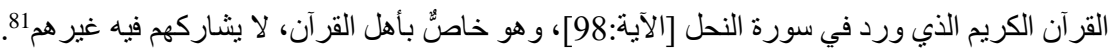

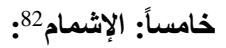

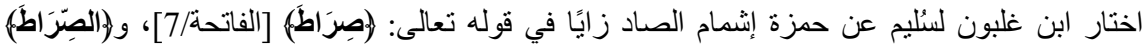

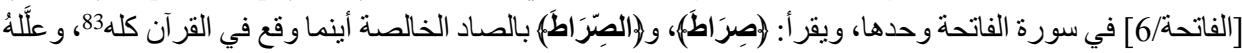

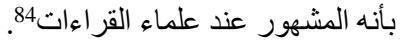

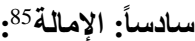

يستعمل علماء القراءات مصطلحات: الإمالة، والإمالة الكبرى، والإمالة المحضة، والإضجاع، للإمالة

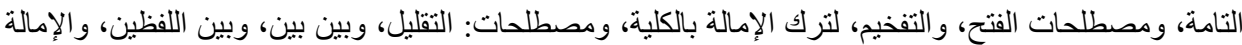

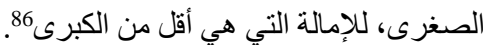

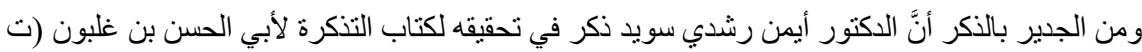

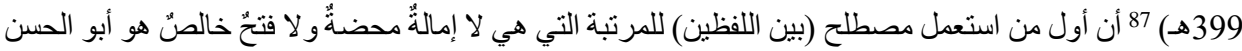

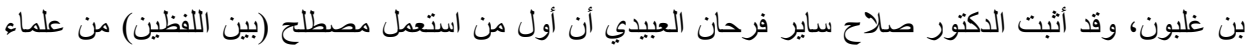

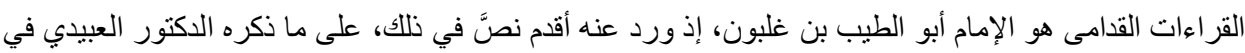
تحقيقه لكتاب الإرشاد الفي

$$
\text { (أ) إمالة (إنَّىَ) التي تأتي للاستفهام وفتحها: }
$$

المشهور عن أبي عمرو البصري إمالتها في القرآن كله من طريقي العر اقيين و الرَّقِيّين. واختار ابن غلبون

فيها الفتح من طريق الرَّقِيّين.

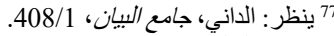

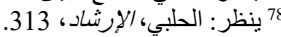

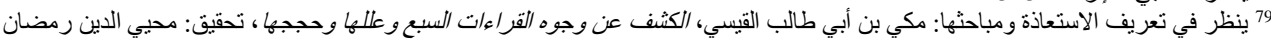

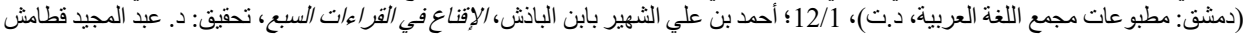

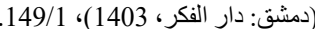
80 ينظر : الحلبي، الإرشاد، العكر، 221.

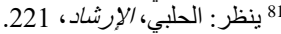

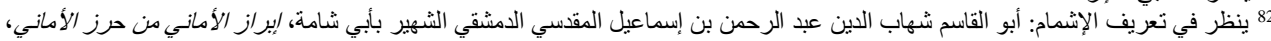

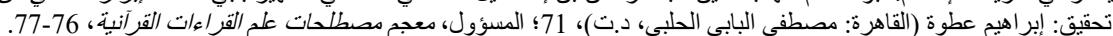

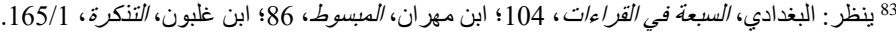
إنظر 84 85 ينظر في تعريف الإمالة: ابن الجزري، إني، النشر في القراءوات العشر ، أشرف على تصحيحه ومر اجعته: علي محمد الضباع (بيروت: دار الكتب العلمية،

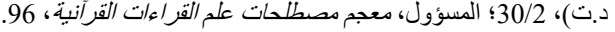

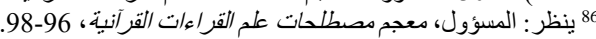

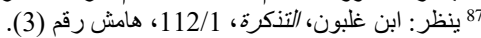

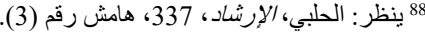

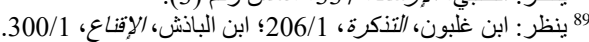




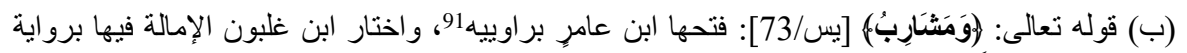

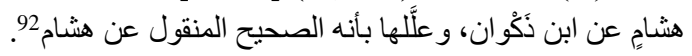

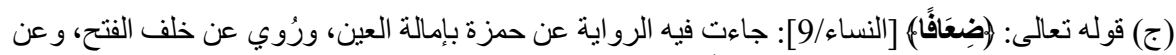

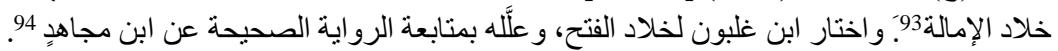

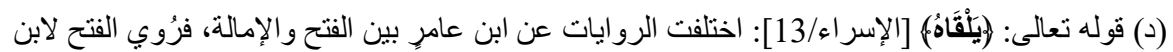

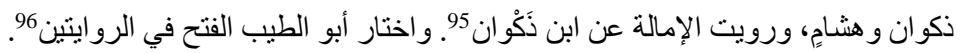

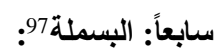

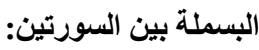

اختار ابن غلبون عدم الفصل بالبسملة بين السورتين، لا بالسكت و لا بالبسملة، في رواية ورش عن نافع 98.

$$
\text { واختار السكت بين السور الأربع الزهر } 99 \text { في قراءة ابن عامرِ، وأبي عمرِو ورواية ورشٍِ } 100 .
$$

و علله بأنه المنقول عن أئمة القراءات 101.

$$
\text { ثامناً: التحريك و الإسكان 102: بـ }
$$

اختار ابن غلبون إسكان الراء من طريق الرَّقَّيِين، والاختلاس من طريق العر اقيين لأبي عمرِو في قوله

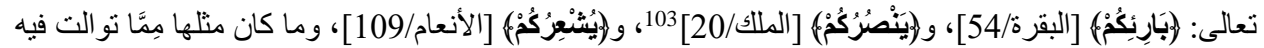

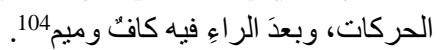

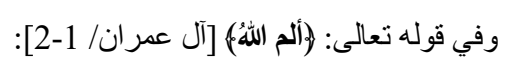

ذهب جمهور القرَّاء إلى فتح الميم في حال الوصل 105، وروي عن شعبة الإسكان فيها، وردَّأبو الطبب رواية

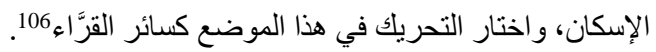

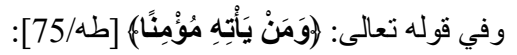

91 ينظر : ابن غلبون، التذكرة، 212/1؛ ابن الجزري، النشر، 49/2.

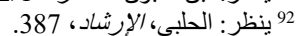

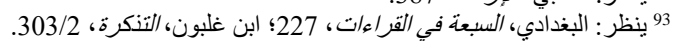
94

95 ينظر : البغدادي، السبعة في القراءاءت، 476، 378؛ 378؛ ابن غلبون، التنكرة، 404/2؛ القيسي، التبصرة، 243. 96 ينظر : الحلبي، الإرشاد، 985 ينظية 97 ينظر في تعريف البسملة ومباحثها: ابن غلبون، التنكرة، 63/1؛ ابن الجزري، النشر ، 204/1-206. 98 99 أي البطملة بين سورة المدثر وإنباد القيامة، وبين الانفطار و المطفقين، وبين الفجر و البلد، وبين العصر و الهمزة. 100 101 ينظر : الحلبي، الإرشاد، الإثاد، 225.

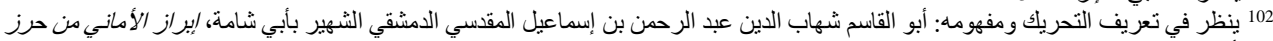

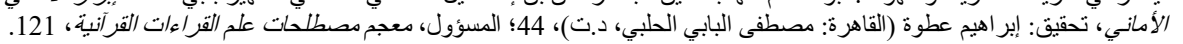
103

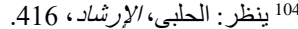

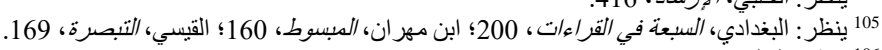
106 ينظر: الحلبي، الإرشاد، 459. 
270

مـا اختاره الإمام أبو الطيب بن غلبون من الروايات والوجوه في كتابه الإرشاد: جمعًا وتحقيقًا

RTEÜirD

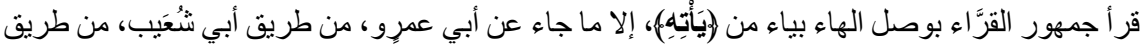

الرَّقِيّين، فإنه قرأ بإسكان الهاء من غير صلة ياء 107.

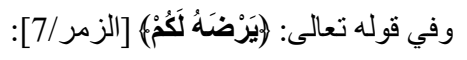

قرأ ابن عامرِ في ما رواه عنه الأخفش بصلة الهاء بواو، واختار ابن غلبون فيها صلة الهاء بواو 109.

وفي قوله تعالى: (خُطُوَات) [في القرآن كله] بين إسكان الطاء وضمها:

اختار ابن غلبون في رواية البَِّّي عن ابن كثيرِ : إسكان الطاء في القرآن كلهبه.

$$
\text { تاسعاً: التكبير 111: }
$$

اختار ابن غلبون صيغة (الله أكبر) في التكبير للَّزّي عن ابن كثيرِ ، فقال: (و التكبير اليوم بمكة: الله أكبر ، لا

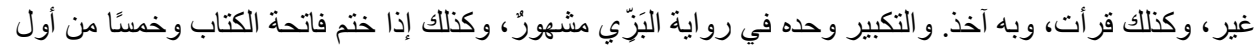

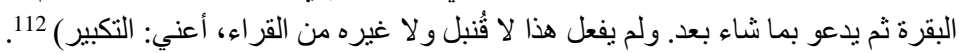

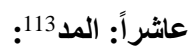

اختار ابن غلبون لنافع من رواية قالون، من طريق أبي نشيطٍ، و أبي عمرِو من طريق ابن مجاهدٍ من طريقي

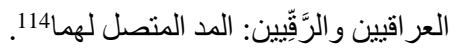

و هو هنا بيتعمل المصطلحات القديمة، إذ استعمل مصطلح: (مد حرف لحرف) 115، وهو من أقام المصطلحات استعمالاً عند ابن مجاهدٍ وتلاميذه، وتلاميذهم، ومنهم ابن غلبون.

\section{1- المد المتصل في كلمة واحدة:}

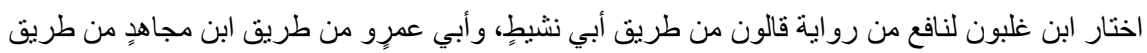

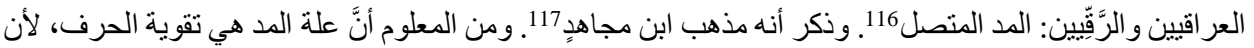

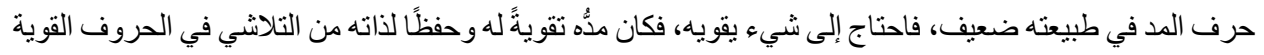
التي معه في الكلمة نفسها.

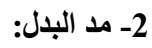

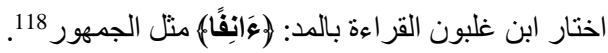

107 ينظر : البغدادي، السبعة في القراء/ت، 212؛ الداني، جامع البيان، 129/2. 108 ينظر : الحلبي، الإرشاد ، 108 109 ينظر : الحلبي، الإرشاد، الإرثاد، 465. 110 ينظر : الحلبي، الإرشاد ، 1093 111 ينظر في مباحيث التنكبير : ابن الجزري، 435، النشر، 405/2؛ المسؤول، معجم مصطلحات علم القراءات القرآنية، 145.

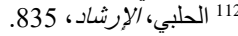

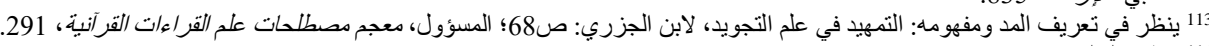
114 115 هو المد الجائز المنفصل، كما في المسؤول، المان، معجم مصطلحات علم القراءات القرآنبية، 294، 295.

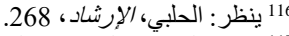
117

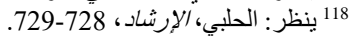




\section{3- القراعة بين المد والهمز:}

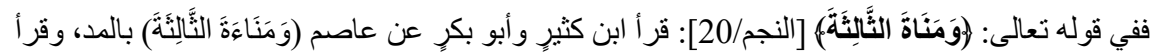
سائر القرَّاءو والرواة عن أبي بكرٍ بالقصر 119.

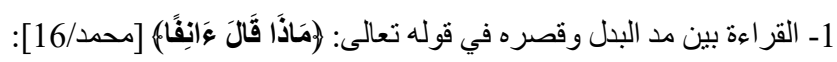

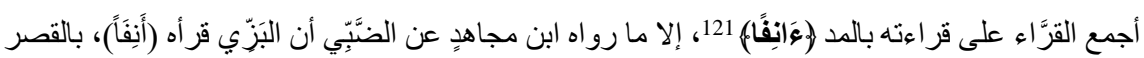

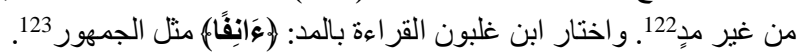

\section{حادي عشر: ميم الجمع124: - مئر}

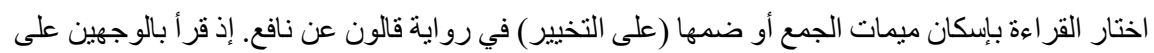

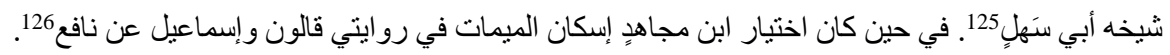

$$
\text { ثاني عشر: هاء الكناية 127: }
$$

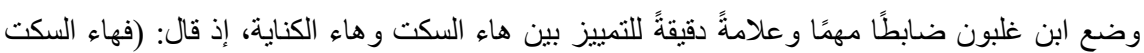

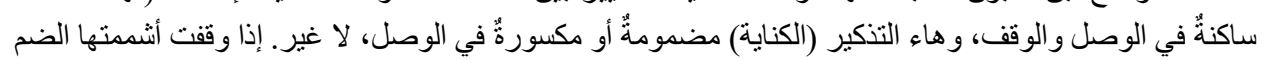

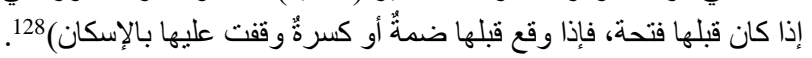

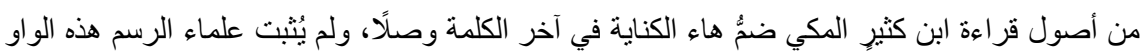

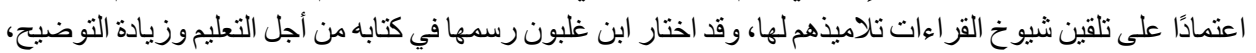

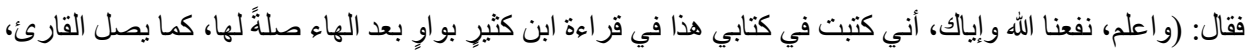

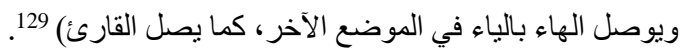

وبيَّن ابن غلبون أن هذا الرسم لا يلزم، و إنما هو للتعليم لا غير ، و أنه يجب في كتابة المصحف التزام الرسم

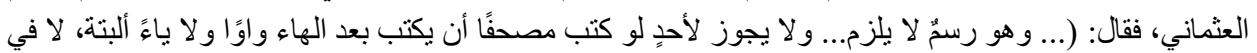

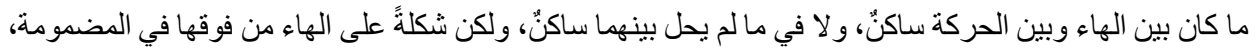

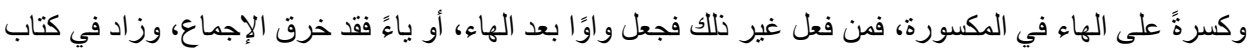

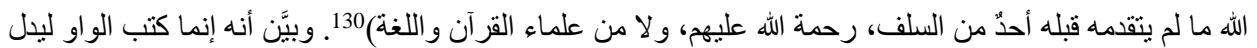

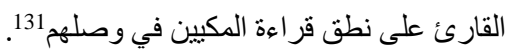

119 ينظر : البغدادي، السبعة في القراء/ت، 614؛ إبن إن غلبون، التنكرة، 569/2؛ القيسي، التبصرة، 338.

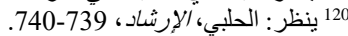

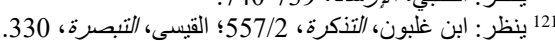
122

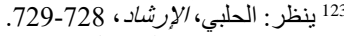

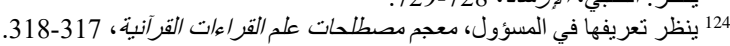

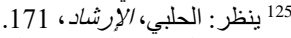

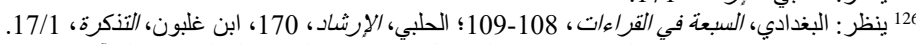

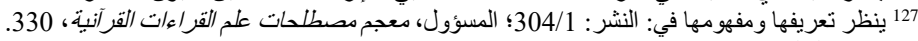

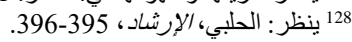
129 230 130 الحلبي، الإرشاد، الإنشاد، 236-236. 131 ينظر: الحلبي، الإرشاد، 237. 


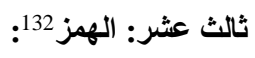

\section{(1) (1) الهمزتان المتفقتان بالكسر في كلمتين:}

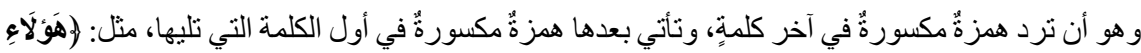

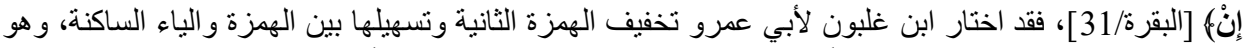

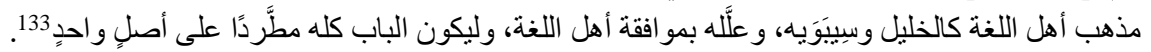

\section{(2) الهمزة المفردة:}

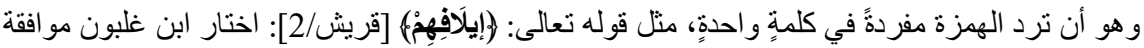

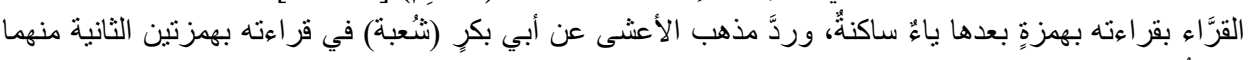
ساكنةٌُ134.

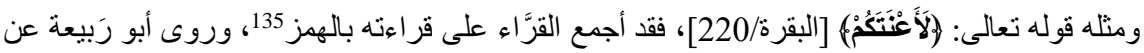

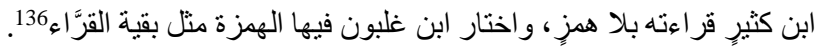

$$
\text { رابع عثر: الوقف137 }
$$

اختار ابن غلبون في الوقف على الهمز الذي قبله ساكنٌ بالروم والإشمام في القراءات كلها، واختار جواز

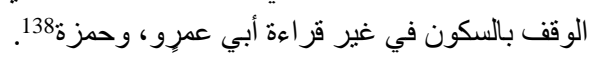

واختار ابن غلبون موافقة سييبوَيه في بيان علامات الضبط، خاصةً في ما يتعلق بحال الحرف عند الوقف

$$
\begin{aligned}
& \text { عليه، ونلك على النحو الآتي: } \\
& \text { (1) علامة الإشمام عنده نقطةٌ فوق الحرف.139. } \\
& \text { (2) علامة السكون خاءٌ فوق الحرف140. } \\
& \text { (3) علامة الرَّوم خطُّ بين يدي الحرف } 141 . \\
& \text { (4لامة التضعيف (التشديد) شينٌ على الحرف المضاعف } 142 . \\
& \text { خامس عشر: ياء الإضافة 143: }
\end{aligned}
$$

اختار ابن غلبون عدم جواز كتابة الياءات المحذوفات من المصاحف، معلاً ذللك بأنه إجماع السلف من علماء الئاء

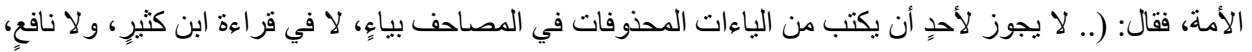

$$
\begin{aligned}
& 132 \text { ينظر الهمز وتعريفه ومباحثه في: المقدسي، /بر/ز الأماني، 115؛ المسؤول، معجم مصطلحات علم القراءات القرآنبة، 332-334. } \\
& 133 \text { ينظر : الحلبي، الإرشاد، العنئ، } 292 . \\
& 134 \text { ينظر : الحلبي، الإرشاد ، } 1335 \\
& 135 \\
& 136
\end{aligned}
$$

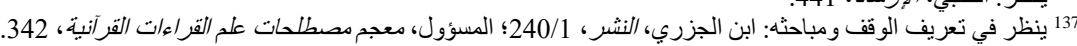

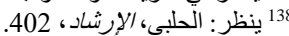

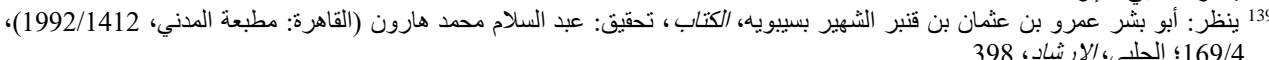

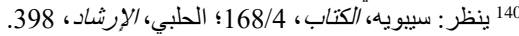

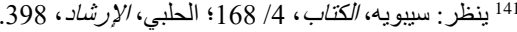

$$
\begin{aligned}
& 142
\end{aligned}
$$




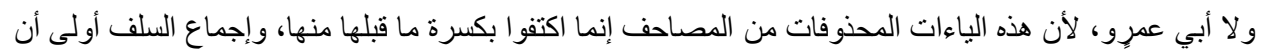

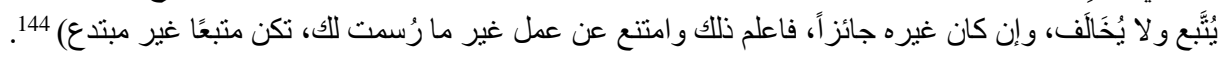
وفي قوله تعالى: (روَمَحْيَايَ) [الأنعام/162]: ذهب أكثر الرواة عن ورش إلى القراءة بإسكان الياء، ومنهم

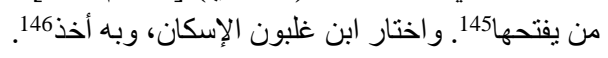

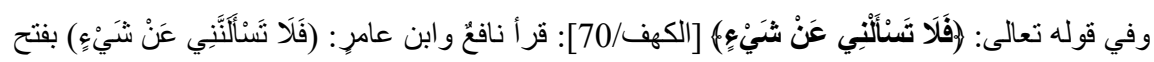

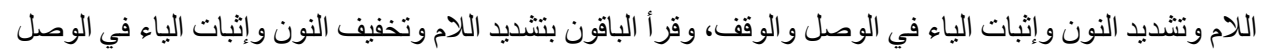

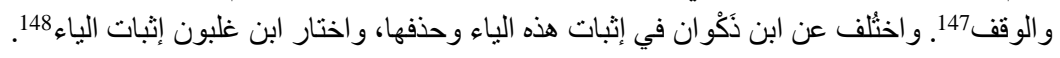

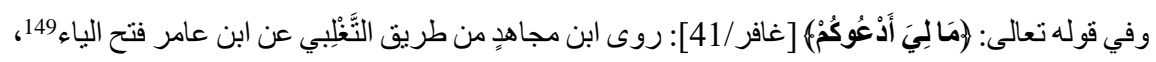

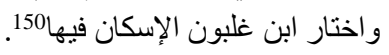

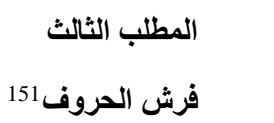

\section{من سورة الأنعام}

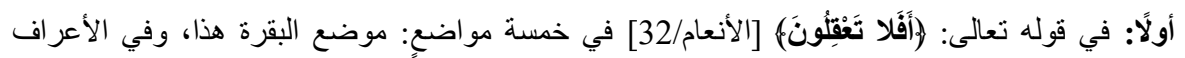

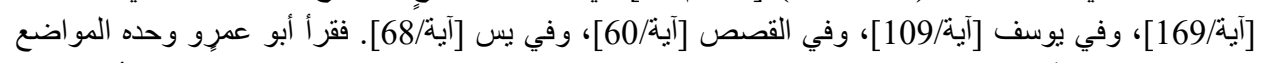

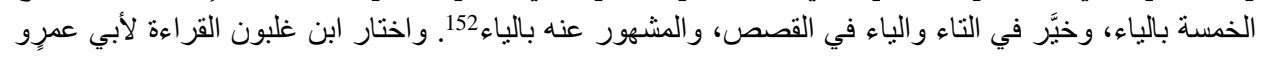
بالياء في هذه المو اضع كلهالئاء، وخئ.

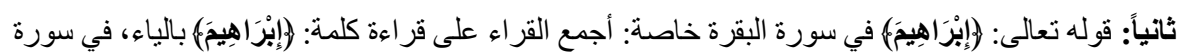

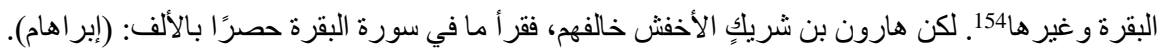

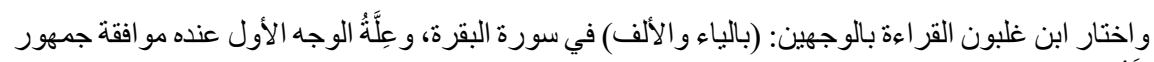

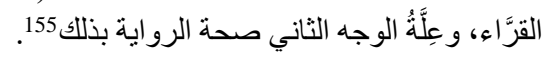

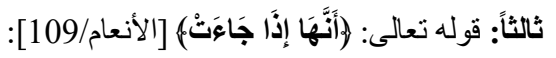

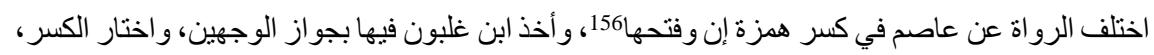

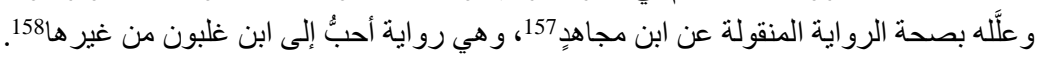

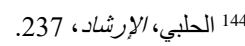
145 145

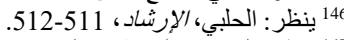

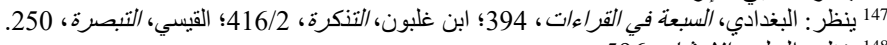
148 ينظر : الحلبي، الإرشاد ، 147

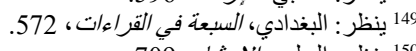

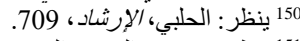

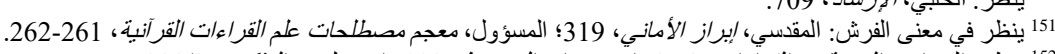

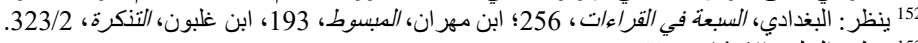
153 ينظر: الحلبي، الإرشاد، 152

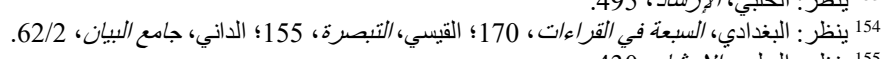
155

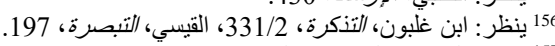
157 158 ينظر : الحلبي، الإرشاد، 157 
ما ما اختاره الإمام أبو الطيب بن غلبون من الروايات والوجوه في كتابه الإرشاد: جمعًا وتحقيقًا

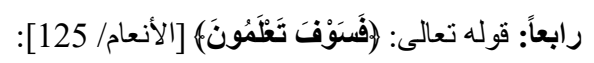

قرأ ابن عامرِ في المشهور عنه بالتاء، وروى ابن مجاهٍٍ من طريق التَّْْلبِي عن ابن عامرِ بالياء (يعلمون)

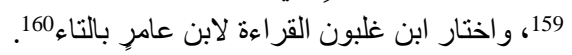

من سورة الأعراف

قوله تعالى: (ليَبَيسِِ) [الأعر اف/165]، و (بَيْنَسِ): أخذ أبو الطيب لعاصم بالوجهين 161.

من سورة الإسراء

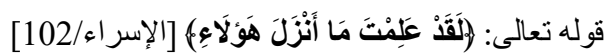

أجمع القرَّاء على فتح التاء، إلا الكسائي، والأعشى عن أبي بكرِ، فإنهما ضمَّا التاء (علمتُ162163، واختار ابن غلبون فتح التاءع أنر

من سورة الزمر

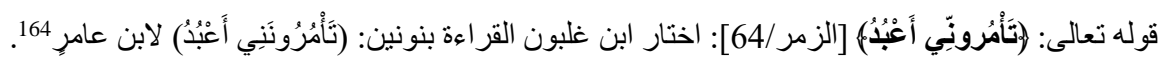

من سورة الثورى

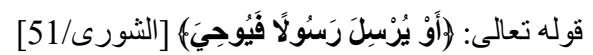

قرأ نافعٌ بضم اللام من (يرسل)، و الياء من (يوحي)، وقرأ الجمهور بفتحهما. إلا ما رواه ابن مجاهدٍ من

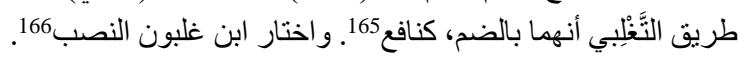

من سورة الزخرف

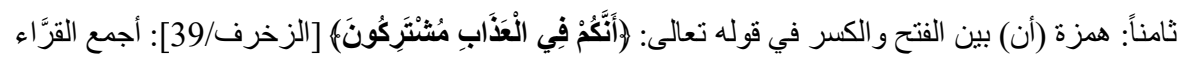

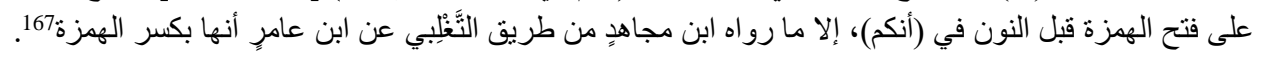

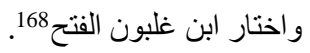

من سورة المجادلة

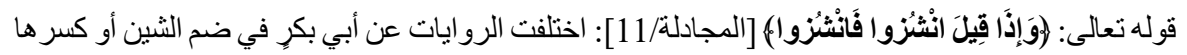

في الموضعين 169، فاختار ابن غلبون الضم في الموضعين لأبي بكرِ 170.

159 ينظر : البغدادي، السبعة في القراء/ت، 169

160 ينظر : الحلبي، الإرشاد، الإن، 190

161 ينظر : الحلبي، الإرشاد، الإنشاد، 525-526.

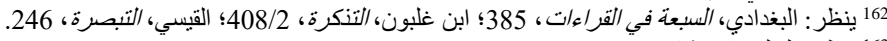

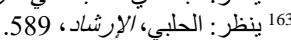

164 ينظر: الحلبي، الإرشاد، الإنشاد، 163.

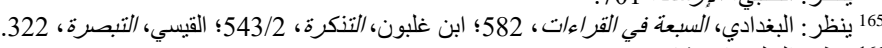

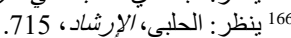

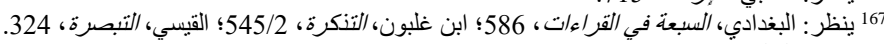

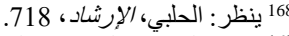

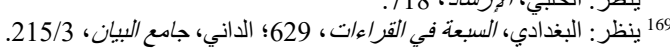
170 ينظر : الحلبي، الإرشاد، 169 


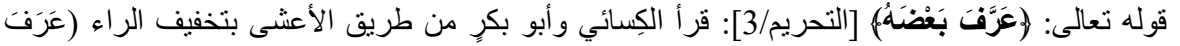

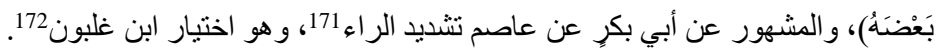

من سورة الجن

قوله تعالى: (وكَادُوا يَكُونُونَ عَلَيْهِه لِبَدًام) [الجن/19]: اختار ابن غلبون في رواية هشامٍ عن ابن عامرٍ ضم اللام2173.

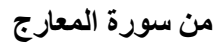

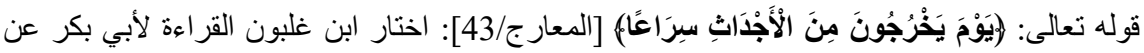

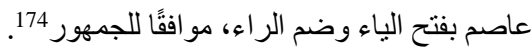

ومن سورة النبأ

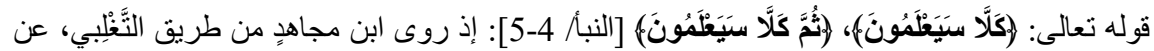

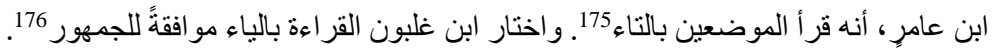

\section{الخاتمة}

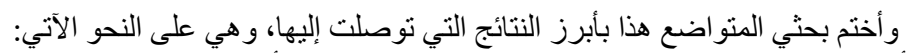

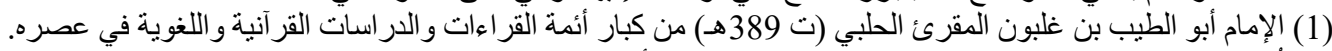

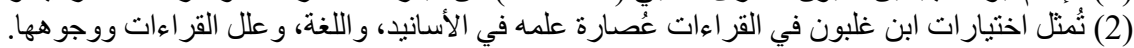

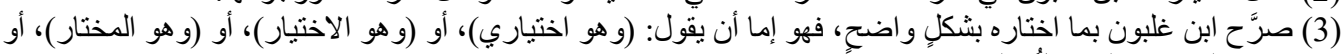

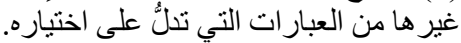

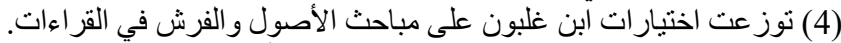

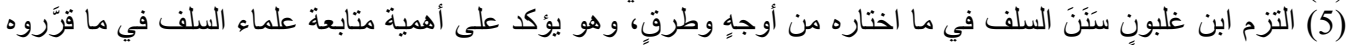

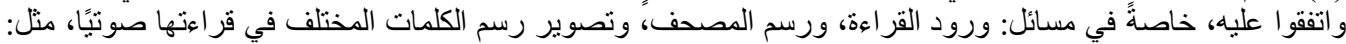

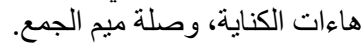


ابن أبي مريم، نصر بن علي الثير ازي الفارسي، العوضح في وجوه القراء/ت وعللها ، تحقيق: د. عمر حمدان الكبيسي، مصر : مكتبة التو عية الإسلامية، 2001/1421.

ابن الباذش، أحمد بن علي الشهير، الإقناع في القراءات السبع، تحقيق: د. عبد المجيد قطامش، دمشق: دار الفكر، 1403. ابن الجزري، أبو الخير، التهعيد في علم التجويد، تحقيق: د. غانم قدوري الحمد، بيروت: مؤسسة الرسالة، 1987/1407

ابن الجزري، أبو الخير، غاية النهاية في طبقات القرَّاء، عني بنشره: ج. براجستراسر، بيروت: دار الكتب العلمية، .2006/1427

ابن الجزري، النشر في القراءات العشر ، أشرف على تصحيحه ومر اجعته: علي محمد الضباع، بيروت: دار الكتب

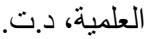

ابن خلكان، أبو العباس شمس الدين أحمد بن محمد، وفيات الاعيان وأنباء أبناء الزمان، تحقيق: احسان العباس، بيروت: دار صادر، 1972.

ابن زنجلة، حجة القراءات ، تحقيق: سعيد الأفغاني، بيروت: مؤسسة الرسالة، د. ت.

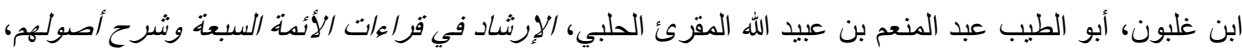
تحقيق ودر اسة: د. صلاح ساير فرحان العبيدي، بيروت: دار ابن حزم - كركوك: مكتبة أمير ، 2015/1436.

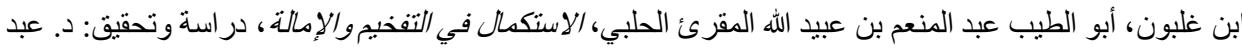
العزيز علي سفر، الكويت: السلسلة التراثية، المجلس الوطني للتقافة و الفنون والآداب، 2001/1422. ابن غلبون، أبو الطيب عبد المنعم بن عبيد الله المقرئ الحلبي، انفرادات القراء السبعة، دراسة وتحقيق: أسامة بن

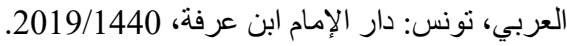

ابن غلبون، أبو الطيب عبد المنعم بن عبيد الله المقرئ، /ختلاف القراء السبعة في الباءات والتاءات والثاءات والنونات التاء والياءات، تحقيق: د. عبد الكريم بن مصطفى مدلج، القاهرة: دار عباد الرحمن، 2012/1433. ابن منظور ، أبو الفضل جمال الدين محمد بن مكرم،لسان العرب ، بيروت: دار صادر، ودار بيروت للطباعة و النشر، 1956/1375

ابن مهران، أحمد بن الحسين، المبسوط في القراءات العشر، تحقيق: سبيع حمزة حاكمي، دمشق: مطبو عات مجمع اللغة العربية، 1980/1401.

أبو الحسن، طاهر بن عبد المنعم بن غلبون ، التنكرة في القر /ءات الثمان، تحقيق: د. أيمن رشدي سويد، مكة المكرمة: 1991/1412

البغدادي، أبو بكر أحمد بن موسى ابن مجاهد، السبعة في القراءات، تحقيق: شوقي ضيف، القاهرة: دار المعارف، 1980. البناء، شهاب الدين أحمد بن محمد بن عبد الغني الدمياطي، إتحاف فضلاء البشر في القراءات الأربعة عشر ، تحقيق:

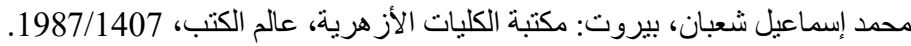
الحمد، غانم قدوري، أبحاث في علوم القرآن، عمان: دار عمار،2006/1426. 
الحموي، أبو الرضا أحمد بن عمر بن محمد، القواعد والإشارات في أصول القراءات، تحقيق: عبد الكريم بن محمد

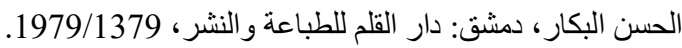

الحنبلي، عبد الحي بن العماد، شذرات الذهب في أخبار من ذهب، القاهرة: مكتبة المقسي، 1350. الداني، أبو عمرو عثمان بن سعيد، جامع البيان في القراءات السبع، تحقيق: مجمو عة من الباحثين، الإمار ات العربية

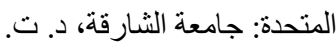

الذهبي، أبو عبد الله محمد بن أحمد، تذكرة الحفاظ، بيروت: دار إحياء التزاث العربي، 1958/1377. الذهبي، شمس الدين أبو عبد الله محمد بن أحمد بن عثمان بن قَايْماز ، العبر في خبر من غبر ، تحقيق: أبو هاجر محمد السعيد بن بسيوني زغلول، بيروت: دار الكتب العلمية، 1985.

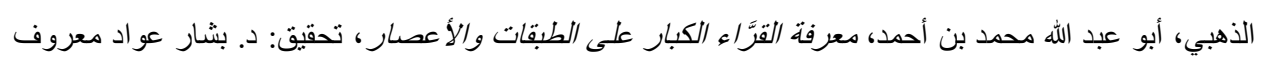

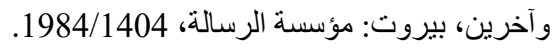

سييويه، أبو بشر عمرو بن عثمان بن قنبر، الكتاب، تحقيق: عبد السلام محمد هارون، القاهرة: مطبعة المدني، .1992/1412

الثوكاني، محمد بن علي، الببر الطالع بدحاسن ما بعد القرن السابع، بيروت: دار المعرفة، د.ت. الضباع، محمد علي، الإضاءة في بيان أصول القراءة، القاهرة: المكتبة الأزهرية للتراث، 1999/1420. فلاته، أمين بن إدريس بن عبد الرحمن، الاختيار عند القرَّاء: مفهومه ومراحله وأثره في القراءات، الرياض: كرسي القرآن الكريم و علومه بجامعة الملك سعود، 1436.

القاضي، عبد الفتاح، البلور الزاهرة في القراءات العشر المتواترة من طريقي الثاطبية والدرة ، راجعه وأعدَّ شو اهده: صبري رجب كريم، القاهرة: دار السلام للطباعة والنشر والتورة النتوزيع، 2013/1434. المسؤول، عبد العلي، معجم مصطلحات علم القراءات القرآنية وما يتعلق به، القاهرة: دار السلام للطباعة والنشر و التوزيع، 2007/1428.

المقسي، أبو القاسم شهاب الدين عبد الرحمن بن إسماعيل الدشقي الثهير بأبي شامة، إبراز الأماني من حرز الأماني، تحقيق: إبر اهيم عطوة، القاهرة: مصطفى البابي الحلبي، د.ت الرئ.

مكي بن أبي طالب القيسي، الإبانة عن معاني القراءات ، تحقيق: محيي الدين رمضان، المملكة العربية السعودية: دار المأمون للتراث، 1979/1399.

مكي بن أبي طالب القيسي، التبصرة في القراءات السبع، تحقيق: د. محمد غوث الندوي، الهند: الدار السلفية، 1982/1402

مكي بن أبي طالب القيسي، الكشف عن وجوه القراءات السبع و علاها وحججها ، تحقيق: محيي الدين رمضان، دمشق: مطبو عات مجمع اللغة العربية، د.ت. 


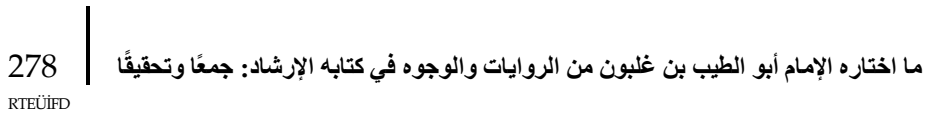

\section{KAYNAKÇA}

Bennâ, Ahmed b Muhammed b Ahmed ed-Dimyâtî. İthâfu fuzalâi'l-beşer fi'l-kırââti'l-erbaate 'aşer. Beyrut-Kahire: 'Alemü'l-Kütüb-Mektebetü'l-Külliyati'l-Ezheriyye, 1987.

Dabbâ', Ali Muhammed. el-İzâe fî beyâni usûli'l-kırâe. Kahire: el-Mektebetü'l-Ezheriyye li't-Türâs, 1999.

Dânî, Ebû Amr Osman b. Saîd. Câmi'u'l-beyân fi'l-kırââti's-seb'ı'l-meşhûra. thk. Heyet. Birleşik Arap Emirlikleri: Şarika Üniversitesi, ts.

Ebü'l-Hasan, Abdülmün'im b. Ubeydullah b. Galbûn el-Mukrî el-Halebî. et-Tezkire fi'lkırââti's-semân. thk. Eymen Rüşdî Süveyd. Mekke: 1991.

Fellâte, Emin b. İdris b. Abdurrahmân. el-İhtiyâr 'inde'l-kurrâ: mefhûmuhû ve merâhilühû ve eseruhû fi'l-kırâât. Riyad: Câmiatü'l-Melik Suud Kürsiyyü'l-Kur'âni'1-Kerîm ve 'Ulûmih, 1436.

Hamed, Gânim Kaddûrî. Ebhâs fî 'ulûmi'l-Kur'ân: el-kırââtü'l-Kur'âniyye-el-mushaf ve resmühtu-i'cazü'l-Kur'ân ve vücûhuhû. Amman: Dâr-u 'Ammar, 2006.

Hamevî, Ebu'r-Rıza Ahmed b. Ömer b. Muhammed. el-Kavâid ve'l-işârât fì usûli'lkırâât. thk. Abdülkerim b. Muhammed el-Hasan el-Bekkâr. Dımaşk: Dâru'lKalem, 1979.

İbn Ebî Meryem, Nasr b. Ali eş-Şîrâzî el-Fârisî. el-Mûdıh fî vücûhi'l-kırâât ve 'ılelihâ. thk. Ömer Hamdân el-Kübeysî. Misır: Mektebetü't-Tev'iyeti'l-İslâmiyye, 2001.

İbn Galbûn, Ebu't-Tayyib Abdülmün'im b. Ubeydullah b. Galbûn el-Mukrî el-Halebî. el-İrşâd fî kırââti'l-eimmeti's-seb'a ve şerhi usîlihim. thk. Salâh Sâyir Ferhân elUbeydî. Kerkük-Beyrut: Mektebet-ü Emir-Dâr-u İbn Hazm, 2015.

İbn Galbûn, Ebu't-Tayyib Abdülmün'im b. Ubeydullah b. Galbûn el-Mukrî el-Halebî. el-İstikmal fi't-tefhîm ve'l-imâle. thk. Abdülaziz Ali Sefer. Kuveyt: es-Silsiletü'tTürâsiyye-el-Melisü'l-Vatanî li's-Sekâfe ve'l-Funûn ve'l-Âdâb, 2001.

İbn Galbûn, Ebu't-Tayyib Abdülmün'im b. Ubeydullah b. Galbûn el-Mukrî el-Halebî. İhtilâfül-kurrâi's-seb'a fi'l-bâât ve't-tâât ve's-sâât ve'n-nûnât ve'l-yâât. thk. Abdülkerim b. Mustafa Mudlic. Kahire: Dâr-u 'Ibâdi'r-Rahmân, 2012.

İbn Galbûn, Ebu't-Tayyib Abdülmün'im b. Ubeydullah b. Galbûn el-Mukrî el-Halebî. İnfirâdâtü'l-kurrâi's-seb'a. thk. Üsâme b. el-'Arabî. Tunus: Dâru'l-İmâm İbn 'Arafe, 2019.

İbn Hallikân, Ebü'l-Abbâs Şemsüddîn Ahmed b. Muhammed. Vefeyâtü'l-a'yân ve enbâu ebnai'z-zamân. Beyrut: Dâr-u Sadr, 1972. 
İbn Manzûr, Muhammed b. Mükerrem. Lisânü'l-'Arab. Beyrut: Dâr-u Sadr, 1956.

İbn Mücahid, Ebû Bekr Ahmed b. Mûsâ el-Bağdâdî. es-Seb'a fi'l-kırâât. thk. Şevkî Dayf. Kahire: Dâru'l-Meârif, 1980.

İbn Zencele. Huccetü'l-kırâât. thk. Saîd el-Efegânî. Beyrut: Müessesetü'r-Risâle, ts.

İbnü'l-Bâziş, Ebû Ca'fer Ahmed b Alî b Ahmed b. Halef Ensârî. el-İknâ' fi'l-kırâ'âti'sseb'. Dımaşk: Dâru'l-Fikr, 1403.

İbnü'l-Cezerî, Ebü'l-Hayr Şemsüddîn Muhammed b. Muhammed b. Muhammed. enNeşr fi'l-kırââti'l-'aşr. thk. Ali Muhammed Dabbâ'. Beyrut: Dâru'l-Kütübi'l'İlmiyye, t.y.

İbnü'l-Cezerî, Ebü'l-Hayr Şemsüddîn Muhammed b. Muhammed b. Muhammed. et-Temhîd fí 'ilmi't-tecvîd. thk. Gânim Kaddûrî Hamed. Beyrut: Müessesetü'r-Risâle, 1987.

İbnü'l-Cezerî, Ebü'l-Hayr Şemsüddîn Muhammed b. Muhammed b. Muhammed. Gâyetü'n-nihâye fi tabakâti'l-kurrâ. thk. Gotthelf Bergstraesser. Beyrut: Dâru'lKütübi'l-'İlmiyye, 2006.

İbnü'l-'İmâd, Ebü'l-Felâh Abdülhay b Ahmed b Muhammed. Şezerâtü'z-zeheb fi ahbâri men zeheb. Kahire: Mektebetü'l-Kudsi, 1350.

Kâdî, Abdülfettah. el-Büdûru'z-zâhira fi'l-kırââti'l-'aşri'l-mütevâtira min tarîkayi'şŞâtıbiyye ve'-Dürra. Kahire: Dâru's-Selâm li't-Tibâ'a ve'n-Neşr ve't-Tevzî, 2013.

Kaysî, Ebî Muhammed Mekki b. Ebî Tâlib. el-íbâne 'an meâni'l-kırâât. thk. el-Fettâh İsmâil Şelebî. Mekke: el-Mektebetü'l-Faysaliyye, 1985.

Kaysî, Ebî Muhammed Mekki b. Ebî Tâlib. el-Keşf 'an vücûhi'l-kırâ'âti's-seb' ve 'ilelihâ ve hucecihâ. thk. Muhyiddîn Abdurrahman Ramazan. Dımaşk: Mecma'u'l-Lügati'l'Arabiyye, ts.

Makdisî, Abdurrahmân b. İsmâîl. İbrâzü'l-me'ânî min Hırzi'l-emâni fî kırâati's-seb'i. thk. İbrâhîm Atve İvaz. Kahire: Mustafa el-Babî el-Halebî, 1982.

Mes'ûl, Abdülalî. Mu'cemü'l-mustalahâti'l-Kur'âniyye. Kahire: Dâru's-Selâm li't-Tibâ'a ve'n-Neşr ve't-Tevzî, 2007.

Nisâbûrî, Ahmed b. Hüseyin İbn Mihran. el-Mebsût fi'l-kırââti'l-'aşr. thk. Hamza Hâkimî Sübey'. Dımaşk: Matbûatü Mecmai'l-Lügati'l-'Arabiyye, ts.

Sîbeveyh, Ebû Bişr Amr b. Osman b. Kanber. el-Kitâb. ed. Abdüsselâm Muhammed Hârûn. Kahire: Matbaatü'l-Medenî, 1992.

Şevkânî, Ebû Muhammed b. Ali. el-Bedrü't-tali' bi-mehasin men ba'de'l-karni's-sabi'. Beyrut: Dâru'l-Ma'rife, ts. 
280 ما اختاره الإمام أبو الطيب بن غلبون من الروايات والوجوه في كتابه الإرشاد: جمعًا وتحقيقًا

RTEÜiFD

Tâlib, Mekki b. Ebû. et-Tebsira fi'l-kırâât fi'l-kırââti's-seb'i. thk. Muhammed Gavs enNedvî. Hindistan: ed-Dâru's-Selefiyye, 1982.

Zehebî, Ebû Abdullah Muhammed b. Ahmed. el-İber fî̀ haberi men gaber. Beyrut: Dâru'1Kütübi'l-'İlmiyye, 1985.

Zehebî, Ebû Abdullah Muhammed b. Ahmed. Tezkiretü'l-huffâz. Beyrut: Dâr-u İhyâi'tTürâsi'l-'Arabî, 1958.

Zehebî, Ebû Abdullah Muhammed b. Ahmed. Ma'rifetü'l-kurrâi'l-kibâr 'ale't-tabakât ve'l-a'sâr. Beyrut: Müessesetü'r-Risâle, 1984. 